\title{
A Case-Series of Solitary Skull Neoplastic Lesions Treated with En-Block Resection and Complex \\ Cranioplasty
}

Keywords: Cranioplasty; Complex reconstruction; Skull tumors; Enblock resection; Multidisc iplinary

\begin{abstract}
Background and aims: Tumors involving the calvarium but extending into the adjacent scalp layers and/or the underlying dura and brain are technically challenging to treat. Patients often present late in the course of disease which results in either iresectable tumor configurations or - if at all feasible- the need for complex resections, the latter involving allograft cranioplasty and duraplasty sometimes in combination with skin grafting to repair surgical defects. This multid isc iplinary study evaluates the outc ome of complex single stage resections treated with allograft cranioplasty and duraplasty some of which required a combination of same-session soft tissue coverage by plastic surgery.
\end{abstract}

Methods: We analyzed the management of 17 such complex cases, including 11 patients with metastases secondary to primary malignancies, 2 cases of meningiomas as well as single cases of squamous cell carcinoma, sarcoma, epidermoid and hemangioma All patients underwent single step tumor resection craniectomy repaired with cranioplasty/duraplasty using a titanium mesh which was augmented by methyl methacrylate. Closure ensued with or without soft tissue coverage by flaps and/or grafts. Multidisciplinary follow-up was pursued to monitor local recurrence and potential wound complications.

Results: Outcome analysis revealed excellent results without wound complications or local recurrence and short hospital stay following the procedure.

Conclusion: Single step en-bloc resection of complex skull lesions with same-session cranioplasty may be an effective option to manage patients with solitary skull tumors whether benign, primary malignant or secondary malignant.

\section{Background}

Cranioplasty is a common neurosurgical procedure to replace a skull defect. Although trauma is the most frequent cause of iatrogenic skull defects, neoplastic skull lesions are also frequently encountered in neurosurgical oncology [1]. Radiotherapy and systemic chemotherapy may be effective for symptomatic calvarial metastases, but neurosurgical options must be considered for select solitary lesions amenable for resection [2]. The safety of en-block resection versus piece meal excision of solitary metastatic lesions of the skull has been established for lesions lying over the dural sinuses [3]. Some tumors may involve the calvarium and extend into the adjacent scalp layers or the underlying dura and brain tissue. Among the adult population, calvarial metastases are shown to be the most common cranial tumor arising from primary carcinoma of the lung, breast, prostate and thyroid amongst others [2,3]. In certain cases this may occur with a breech in integumental integrity necessitating wide margin surgical excision and complex layer by layer reconstruction.

\section{Journal of Surgery}

Ahmed B. Bayoumi ${ }^{1}$, Fares Nigim ${ }^{1}$, Anand Mahadevan ${ }^{5}$, Matthew Anderson ${ }^{4}$, Samuel J. Lin ${ }^{2,3}$ and Ekkehard M. Kasper ${ }^{1 *}$

${ }^{1}$ Division of Neurosurgery, Beth Israel Deaconess Medical Center, Harvard Medical School, Boston, MA, USA

${ }^{2}$ Division of Plastic Surgery, Beth Israel Deaconess Medical Center, Harvard Medical School, Boston, MA, USA

${ }^{3}$ Division of Otolaryngology, Department of Surgery, Beth Israel Deaconess Medical Center, Harvard Medical School, Boston, MA, USA

${ }^{4}$ Department of Pathology, Beth Israel Deaconess Medical Center, Harvard Medical School, Boston, MA, USA

${ }^{5}$ Department of Radiology, Beth Israel Deaconess Medical Center, Harvard Medical School, Boston, MA

*Address for Correspondence

Ekkehard M. Kasper, MD, PhD, Division of Neurosurgery, Beth Israel Deaconess Medical Center, Harvard Medical School, 110 Francis Street, Lowry Suite 3B, Boston, MA 02215, USA, E-mail: ekasper@bidmc.harvard.edu

Copyright: (c) 2015 Bayourni Ab, et al. This is an open access article distributed under the Creative Commons Attribution License, which permits unrestricted use, distribution, and reproduction in any medium, provided the original work is properly cited.

Submission: 08 January 2015

Accepted: 10 February 2015

Published: 14 February 2015

This is done with dual intent: for better cosmetic outcome as well as for better tumor control which lowers the incidence of recurrence and seizures [4-7]. However, only a few series with a limited number of patients were published over the last two decades demonstrating the different surgical approaches applying the concept of en-block resection together with cranioplasty $[2,3,8]$.

In this case-series, we evaluated the outcome of such complex single-stage tumor surgeries treated interdisciplinarily with a sequential algorithm of 1) neurosurgical resection, 2) reconstruction via allograft duraplasty and allograft cranioplasty and 3) additional simultaneous soft tissue coverage obtained via flaps or free tissue grafts provided by a plastic surgery team if needed. This case-series will add substantially to the pool of the previously published series and enrich the literature by focusing on outcomes of combined approaches for the management of solitary calvarial tumors whether benign, primary malignant or metastases.

\section{Methods}

We retrospectively reviewed the electronic medical records of 17 cases observed at our institution since 2005 with solitary neoplastic skull lesions operated in the MRI era until the end of 2014. All patients underwent "en-block tumor resection" with variable degrees of complex reconstruction including allograft cranioplasty and plastics closures tailored to the extent and type of the underlying lesion.

All cases were operated on by the senior author. A titanium mesh (Synthes ${ }^{\circledR}$, Zuchwil, Switzerland) with methylmethacrylate matrix soaked in antibiotic solution (Bacitracin) was used for all cases to generate an individually suitable allograft implant, except for one case in which we used a prefabricated antibiotic enriched medpor ${ }^{\circledR}$ allograft (Portage, Michigan). The allograft was custom molded and fixed to the surrounding healthy bone by circumferential miniplates and screws. Biosynthetic allograft duraplasty (Duraform ${ }^{\circledR}$, Raynham, MA) was performed in all cases in which pericranium could not be harvested. Regional skin reconstruction was performed by the plastic 
Citation: Bayoumi AB, Nigim F, Mahadevan A, Anderson M, Lin SJ, et al. A Case-Series of Solitary Skull Neoplastic Lesions Treated with EnBlock Resection and Complex Cranioplasty. J Surgery. 2015;3(1): 8.

surgery team in 5 cases for wound coverage during the same surgical session.

All patients were seen in regular postoperative follow up at 2 weeks and 3 months after surgery, except for one case in which the patient was transferred out. Further follow up was done according to the underlying histopathology and/or the natural history of the disease. There were two patients, who were followed for shortened periods only as they succumbed to their index disease shortly after surgery. The data collection of this study was done under an approved IRB in our institution for retrospective studies.

\section{Results}

Results are shown collectively and individually for patients included in this series in Tables 1 and 2, respectively.

\section{Demographics}

Mean age of the patients in this mixed cohort was 62 years (range: 20 to 85 years). The study group consisted of 7 males and 10 females. All patients with malignant lesions had a presurgical KPS (Karnofsky Performance Status Scale) above 70 with controlled systemic disease.

\section{History \& clinical presentations}

Out of our 17 cases, 7 presented with a scalp mass, 3 with scalp defect, 3 patients had elevated ICP symptoms, 2 patients had an additional focal neurological deficit and 2 cases were incidentally discovered during routine follow up for other conditions. 6 patients had a past surgical history of a previously treated skull lesion.

\section{Radiological findings and management}

The average diameter of lesions was about $4 \mathrm{~cm} .15$ cases were supratentorial and two cases involved the posterior fossa. 6 cases showed evidence of transdural brain invasion requiring intraoperative microscopic dissection of brain parenchyma. 5 cases showed superficial transperiosteal extension with scalp soft tissue invasion and required additional interventions by plastic surgery (e.g. rotational flaps or free myofascial flaps using Serratus anterior or Latissimus dorsi muscle with microvascular anastomoses and/ or split thickness skin grafting). 2 cases required medial extension with microscopic brain dissection and superficial extension as well as plastic surgery for soft tissue coverage. In 2 cases, the lesions remained completely intraosseous. 3 cases (anaplastic meningioma, metastatic carcinoma form the lung and another from the liver) required focal postoperative radiation therapy while 2 cases (metastatic lesion from the breast and another one from the pancreas) had adjuvant whole brain radiation (WBXRT) following surgery.

Only one case of a paramedian frontal scalp lesion (squamous cell carcinoma) showed an ipsilateral frontal air sinus involvement prompting the need for a bifrontal craniotomy followed by sinus exenteration after excising the tumor. The mucosa was stripped by cauterization and fibrin sealant (Tisseel ${ }^{\circledR}$, Baxter, UK) was usedto close the ostia of the sinus. The sinus was irrigated with bacitracin and packed with bacitracin soaked Gelfoam ${ }^{\circledR}$ as well as a well-fitted piece of fat from the donor site of the muscle flap. The tumor invading the brain was surgically resected by microscopic dissection and a partial frontal lobotomy was needed for adequate resection.

\section{Pathology}

9 lesions were of metastatic origin (5 breast cancers, 1 bronchogenic carcinoma "non-small cell or NSCLCA", 1 prostate cancer, 1 pancreatic cancer and 1 hepatocellular carcinoma), 4 cases were from primary malignant tumors (dermatofibrosarcoma protuberans, sarcoma, squamous cell carcinoma and anaplastic meningioma), 1 case was classified as an atypical meningioma (WHO grade II) and 3 cases were of benign histology (cavernous hemangioma, epidermoid and hemangiopericytoma).

\section{Follow up and outcome}

The mean period of postoperative hospital stay was 6.9 days. Follow up periods varied according to primary disease and ranged from 3 to 72 months. 2 patients had shorter follow up period as they succumbed to their underlying disease within the first month after surgery. Overall the patients in this heterogeneous group did rather well, given the lack of suitable treatment alternatives. Out of our 17 cases, there was no reported case of postoperative wound infection even for the cases that had postoperative radiotherapy or frontal air sinus involvement.

However, complications in this difficult to treat series were not infrequent: $5 / 17$ patients did show some form of neurological complications after surgery, amongst those 2 cases with frank neoplastic brain invasion. Early postop complications included: 1 intraparenchymal contusion/hematoma, 1 recurrent chronic subdural hematoma, $1 \mathrm{MCA}$ infarct, 1 delayed postoperative CSF leak (at 3 months after adjuvant radiation) and 1 patient with an increase in sensory seizure frequency (at 6 months). The case with a delayed post radiation CSF leak after 3 months was managed surgically by removing the prosthetic plate and primary closure of the wound in layers.

One other type of complication was observed following plastic surgery closures ( 1 out of 5 cases requiring plastic intervention). This particular patient had an impending flap ischemia on Doppler exam with development of a hematoma at the anastomotic site in the neck, which prompted a re-exploration of the Latissimus dorsi muscle flap microvascular anastomosis, repair of a bleeding vessel and repeat autologous muscle graft from a new donor site (Sternocleidomastoid muscle). As pointed out above, 2 patients passed away within the first month, one patient from stroke and another from a recurrent malignant subdural collection, which made the family to elect comfort measures only respectively).

No local disease recurrence was observed during the reported follow up period except for one case illustrated below (case 2). However, there was another metastatic case of HCC (hepatocellular carcinoma) showing occurrence of two new skull lesions far away from the treated lesion at 16 months after surgical resection, which were then treated with SRS (stereotactic radiosurgery).

\section{Case illustration (1)}

A 58-year-old female patient presented with a right-sided retroauricular swelling of 2 months duration associated with nausea and vomiting. The mass was progressively increasing in size over the last weeks following a 6-month period of diarrhea and weight loss. A past medical history of depression and irritable bowel syndrome 
Citation: Bayoumi AB, Nigim F, Mahadevan A, Anderson M, Lin SJ, et al. A Case-Series of Solitary Skull Neoplastic Lesions Treated with EnBlock Resection and Complex Cranioplasty. J Surgery. 2015;3(1): 8.

was noted. A Head-CT was performed showing a right extra-axial destructive lesion centered over the petromastoid region eroding the outer and inner tables of the skull with possible involvement of the transverse venous sinus and significant perifocal edema. CT abdomen also revealed multiple liver lesions with minimal ascites. The HeadMRI showed a large mass measuring 4.7 X 4.1 X $4.3 \mathrm{~cm}$ extending 5 $\mathrm{mm}$ beneath the intact skin to involve the extra-axial, subdural and subarachnoid spaces (Figure 1). High probability of brain invasion was reported. Possible differential diagnoses put "metastatic lesion" at the top of the list because of multiple suspicious lesions of the liver. More remote considerations included: atypical meningioma, hemangiopericytoma, chondrosarcoma and plasmacytoma, whereas aggressive endolymphatic sac tumor and paraganglioma (glomus tumor) were unlikely given the sparing of the structures of the otic capsule and lack of hypervascularity, respectively.

An excisional craniectomy with same-session cranioplasty was planned as outlined above. An additional microscopic brain dissection was done in order to resect the tumor with no need for any further soft tissue reconstruction as the overlying skin and soft tissue were completely intact. Partial mastoidectomy was also performed as both mastoid and petrous bones were densely infiltrated and the exposed bone was waxed in order to seal the remaining mastoid air cells.

Repair included an onlay-dural allograft (Duragen ${ }^{\circledR}$, Integra, Plainsboro, NJ) which was applied for duraplasty before the stage of bone reconstruction. The latter was tailored with an allograft repair using a molded titanium mesh to accommodate the contour of the skull defect. The mesh was secured circumferentially with the miniplates and screws. Methacrylate was used to fill the defect and to stabilize the construct. The wound was carefully irrigated with copious amounts of bacitracin and warm saline until the cement was hardened. Histopathology revealed a metastatic pancreatic cancer and a whole brain radiation (WBXRT) was done two weeks following surgery. There was no evidence of any surgical complication until the patient represented 3 months after radiation with a clear fluid spillage from the surgical bed suggestive of CSF leakage s/p adjuvant radiation. At that point the prosthetic plate was surgically removed with primary closure of the wound in layers.

\section{Case illustration (2)}

A 76-year-old male patient presented to our clinic with an erythematous right frontal mass protruding out from the skull bone infiltrating the scalp and crossing the midline. Past medical history was notable for atrial fibrillation for which the patient was on digoxin, amiodarone and warfarin. The patient had a remarkablylong past surgical history of multiple recurrences of an atypical meningioma (WHO grade II) at the same anatomical location. The condition started 8 years prior when he experienced forgetfulness, lack of energy and impaired daily physical activities. The tumor had been resected 3 times at another facility by conventional craniotomies and he was further treated with involved-field radiation with a dose of 5760 cGy8 weeks after the $2^{\text {nd }}$ resection. He also had subsequently been treated by stereotactic radiosurgery to $1500 \mathrm{cGy}\left(\mathrm{CyberKnife}{ }^{\circledR}\right)$ for a focal right supraorbital recurrence. The third resection was performed with methacrylate cranioplasty and was followed by chemotherapy (5 cycles of temozolamide at $100 \mathrm{mg} / \mathrm{m}^{2}$ monthly). However, he presented to our brain tumor clinic with evidence of a $4^{\text {th }}$ recurrence. A complex resection/cranial reconstruction was planned (Figure 2) using the previously discussed technique with the intent of offering subsequent stereotactic radiosurgery to the resection cavity (3000 cGy) in combination with further temozolamide (25 $\mathrm{mg} / \mathrm{m}^{2}$ ) on daily basis. The histopathology showed an evidence of malignant transformation to an anaplastic meningioma (WHO grade III). Surgery was successful but the patient had a $5^{\text {th }}$ recurrence 29 months following this complex en-block resection with markedly impaired cognitive function. At that time another complex bifrontal cranioplasty was performed in collaboration with the plastic surgery team as the lesion had infiltrated not only the bone crossing the midline but also involved all layers of the scalp prompting the need for complex skin closure by a local rotational flap and subgaleal release. An image-guided resection was performed to achieve free margins and autologous healthy pericranial autograft was also harvested for duraplasty together with synthetic dural allograft. Once again a gross total resection was achieved intraoperatively. Postoperatively, the patient did well. He had a persistent memory deficit and sustained a relatively small right intraparenchymal contusion which was treated conservatively.

\section{Discussion}

Cranioplasty has been widely used in clinical practice with a relatively low rate of complications. In our case-series, the challenge of resection and reconstruction among our patients stems from the extension of some ( 9 out of 17) neoplastic lesions over several layers,
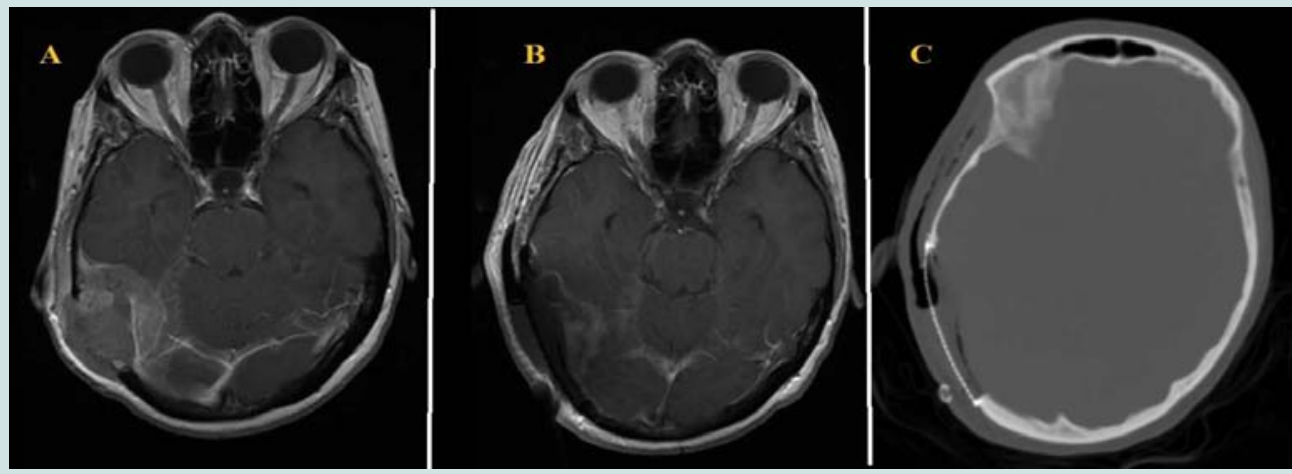

Figure 1: A) Preoperative axial cut of Head-MRI: T1 post contrast showing an extra-axial occipito-temporal metastatic lesion from a pancreatic cancer. B) Postoperative MRI: T1 post contrast, C) Postoperative Head-CT in a bone window showing the skull implant after resection. 

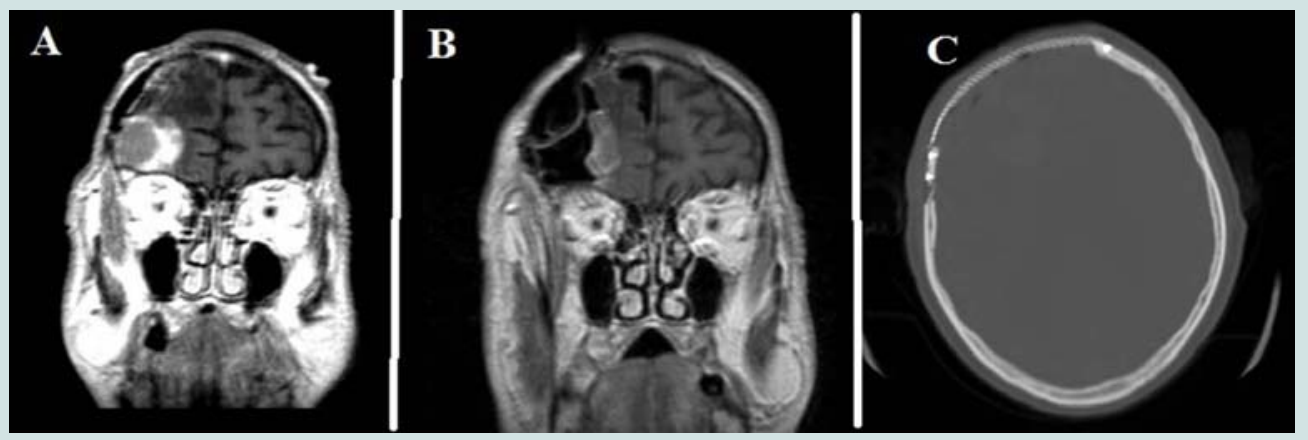

Figure 2: A) Preoperative coronal cut of Head-MRI: T1 post contrast showing an extra-axial frontal lesion representing recurrent atypical meningioma. B) Postoperative MRI: T1 post contrast , C) Postoperative axial-cut Head-CT in bone window showing the skull implant after resection.

invading both the underlying meninges and brain tissue, or the overlying skin and subcutaneous tissue or occasionally both.

One particular problem arises from the need of allograft canioplasty to close the post-resection defect. PMMA (polymethyl methacrylate) cement has been criticized by Pikisand his colleagues based on an assumed neurotoxic effect of PMMA, mostly due to thermal damage or chemical toxicity to the cortex during implant hardening. This aspect is of particular importance in scenarios in which the dura was violated [9]. Although PMMA was also used for most of our patients (except one case where medpor ${ }^{\circledR}$ was used), no encephalopathy or cranial nerve neuropathy was noted postoperatively. PMMA has a number of advantageous properties reported previously: smooth contouring, biocompatibility and no imaging artifacts on CT- or MRI imaging for postoperative evaluation. However, there are reports in the literature cautioning against its use due to cases which resulted in a "bone cement implantation syndrome" giving rise to a serious life-threatening condition characterized by hypoxia, hypotension, arrhythmias and death [10,11]. We were less concerned about these rare reports based on the fact is that such devastating effects occurred from usage of PMMA in the setting of dental or orthopedic interventions with possible unintended translocation $[12,13]$ in which cement was more easily displaced from the surgical field, or gained access to the circulation. The application of PMMA over an extra-axial layer of the skull vault (to cover the titanium mesh filling a bony defect), can be well controlled and makes vascular damage and cement displacement highly unlikely. Notably, copious irrigation with saline also ameliorates any undesirable exothermal effect which might occur in case of direct contact of the allograft with adjacent viable tissue. In addition, we think that allograft duraplasty contributes to isolating the heat effect.

The technique presented here showed a favorable outcome in selected patients. Complex osseous reconstruction using autologous bone grafts has recently been reported by Lee and colleagues in a series where they used vascularized rib, scapula, ilium or combination of any in order to tackle high-risk composite cranial defects. Their cases were challenging from prior or concurrent infection, radiation therapy or cerebrospinal fluid leak or a combination thereof [7]. Although, these authors showed favorable outcomes in terms of eradication of any infection with successful soft tissue reconstruction (0 rate of flap loss in previously intractable cases), only 9 patients (out of 14) in their series had an underlying neoplastic lesion where all of them were malignant. In our study cohort, we present a different scenario of 17 cases with a neoplastic process. This cohort illustrates the wide applicability of this technique to benign, primary malignant or secondary malignant tumors and allows tackling of various types of tumors that may involve the skull alone or extends into the adjacent tissue planes.

Acceptable rates of infection-induced failures of skull implants were reported with cranioplasty using synthetic biomaterials although autologous bone grafts are known to be more resistant to infection [14]. The durability of Titanium against infection was shown in a retrospective study of 151 custom-made titanium cranioplasty conducted by Williams and colleagues [15]. They reported only 6 patients (out of 149) developing late infections requiring removal of implants. 4 out of those 6 patients had a history of previous infection at the site of the defect which might explain the absence of any observed infection in our series as we did not have any patients with preoperative active infection at the site of surgery.Williams and colleagues explained their low rate of infection by their management of paranasal air sinuses which were obliterated prior to cranioplasty. This technique is similar to the one used one patient in our series (as shown above in the results). Furthermore, they reported several case series [16-19] using titanium implants with an overall rate of infection of $2.9 \%$ if calculated. That is in line with the $0 \%$ rate of infection reported by Ducic et al. who used the hydroxyapatite cement with titanium in cases of cranioplasty and who followed them for 6 months to 3 years [20]. On the other hand, PMMA showed higher rates of infection (11\% if calculated) compared to titanium based constructs in many published studies [17,18,21-27]. That observation is further supported by Afifi and colleagues who discouraged the methylmethacrylate use for unfavorable local conditions such as previous infection, radiotherapy or exophytic tumors [28]. Patients selected by our team still showed good outcomes with both titanium and methylmethacrylate cement by avoiding compromised local tissue quality (e.g. from radiation) and selecting lesions not showing signs of active infection at time of surgery. We had only one case (out of 17) having a previously locally irradiated "recurrent atypical meningioma" which is discussed more comprehensively in case illustration number 2 .

What makes this approach appealing is, the fact that we used a simple strategy of conventional cranioplasty employing familiar synthetic alloplastic materials such as Titanium mesh which is widely 
Citation: Bayoumi AB, Nigim F, Mahadevan A, Anderson M, Lin SJ, et al. A Case-Series of Solitary Skull Neoplastic Lesions Treated with EnBlock Resection and Complex Cranioplasty. J Surgery. 2015;3(1): 8.

available and has favorable properties such as stability, durability, is light-weight and represents a chemically inert structure [29]. It also provides easy applicability, no need for smoothing to fit the contours of the calvaria, and postoperatively MRI compatibility. This makes the technique appealing and less cumbersome than split clavarial grafts which remain a valuable asset for select cases of autologous bone grafting, as shown in two complex cases from Lee's series [7].

In a retrospective cohort study conducted by Al-Tamimi's, the authors compare acrylic (PMMA) to Titanium implants in a

Table 1: Shows the descriptive statistics of the patients included in our series showing the different types of surgical interventions and the reported complications.

\begin{tabular}{|c|c|c|}
\hline Characteristics & Value (\%) & Comments \\
\hline $\begin{array}{l}\text { Age, yrs } \\
\text { Mean } \\
\text { Range }\end{array}$ & $\begin{array}{l}61.8 \\
20-85\end{array}$ & \\
\hline $\begin{array}{l}\text { Tumor type } \\
\text { Benign } \\
\text { Primary malignant } \\
\text { Secondary malignant "metastatic" }\end{array}$ & $\begin{array}{l}4(23.5 \%) \\
4(23.5 \%) \\
9(64.3 \%)\end{array}$ & $\begin{array}{l}\text { Benign lesions include "hemangioma, hemangiopericytoma, epidermoid and } \\
\text { atypical meningioma (WHO grade II)" }\end{array}$ \\
\hline $\begin{array}{l}\text { Lesion size, } \mathrm{cm}^{2} \\
\text { Mean } \\
\text { Range }\end{array}$ & $\begin{array}{l}18.3 \\
2-100\end{array}$ & \\
\hline $\begin{array}{l}\text { Extent of Lesion } \\
\text { Skull only } \\
\text { Skull + brain invasion } \\
\text { Skull + soft tissue invasion } \\
\text { Skull + combined brain \& soft tissue invasion }\end{array}$ & $\begin{array}{l}8(47.1 \%) \\
4(23.5 \%) \\
3(17.6 \%) \\
2(11.8 \%)\end{array}$ & \\
\hline $\begin{array}{l}\text { Implant material for bone reconstruction } \\
\text { Titanium mesh + MMA cement } \\
\text { Medpor }{ }^{\circledR}\end{array}$ & $\begin{array}{l}16(94.1 \%) \\
1(5.9 \%)\end{array}$ & MMA = methylmethacrylate \\
\hline $\begin{array}{l}\text { Plastic surgery interventions } \\
\text { Free muscle flap } \\
\text { Rotational flap } \\
\text { Skin graft } \\
\text { Muscle graft } \\
\text { Scalp advancement } \\
\text { Subgaleal release }\end{array}$ & $\begin{array}{l}5(29.4 \%) \\
3 \\
2 \\
4 \\
1 \\
1 \\
1\end{array}$ & $\begin{array}{l}\text { Those techniques were differently combined over the } 5 \text { cases according to the } \\
\text { surgical necessity for appropriate closure. } \\
\text { Muscle flaps were serratus anterior or latissimus dorsi muscles }\end{array}$ \\
\hline Previous excision or reconstruction attempt & $5(29.4 \%)$ & \\
\hline $\begin{array}{l}\text { Adjuvant therapy } \\
\text { Conventional radiotherapy } \\
\text { Stereotactic radiosurgery } \\
\text { Chemotherapy }\end{array}$ & $\begin{array}{l}2(22.2 \%) \\
3(33.3 \%) \\
6(66.7 \%)\end{array}$ & $\begin{array}{l}\text { Percentages are calculated out of the } 9 \text { malignant cases } \\
\text { CyberKnife }{ }^{\circledR}\end{array}$ \\
\hline $\begin{array}{l}\text { Follow-up period, months } \\
\text { Minimum } \\
\text { Mean } \\
\text { Range }\end{array}$ & $\begin{array}{l}3 \\
21.6 \\
3-72\end{array}$ & \\
\hline Complications & & \\
\hline $\begin{array}{l}\text { Neurosurgical(out of } 17 \text { cases) } \\
\text { CNS infection } \\
\text { Seizures } \\
\text { Infarction } \\
\text { Intracranial hemorrhage } \\
\text { CSF leak } \\
\text { Brain Herniation }\end{array}$ & $\begin{array}{l}0(0 \%) \\
2(11.8 \%) \\
1(5.9 \%) \\
2(11.8 \%) \\
1(5.9 \%) \\
1(5.9 \%)\end{array}$ & $\begin{array}{l}\text { Sensory seizures } \\
\text { Brain invasion; MCA branch was sacrificed } \\
\text { Intraparenchymal hematoma, recurrent SDH } \\
\text { Developed after adjuvant radiation therapy } \\
\text { Uncal\&subfalcine herniation due to SDH }\end{array}$ \\
\hline Plastics (out of 5 cases) & & \\
\hline $\begin{array}{l}\text { Impending flap ischemia } \\
\text { Hematoma }\end{array}$ & $\begin{array}{l}1 \\
1\end{array}$ & $\begin{array}{l}\text { Re-exploration of right latissimus flap microvascular anastomosis }+ \text { drainage of } \\
\text { neck hematoma+repair of the bleeding branch of reverse saphenous }+ \text { autologous } \\
\text { muscle graft from sternocleidomastoid }\end{array}$ \\
\hline $\begin{array}{l}\text { Impaired wound healing } \\
\text { Wound infection }\end{array}$ & $\begin{array}{l}0 \\
0\end{array}$ & \\
\hline Systemic (out of 17 cases) & $1(5.9 \%)$ & Progressive systemic disease with leptomeningeal spread, cellulitis and septic shock \\
\hline
\end{tabular}


Citation: Bayoumi AB, Nigim F, Mahadevan A, Anderson M, Lin SJ, et al. A Case-Series of Solitary Skull Neoplastic Lesions Treated with EnBlock Resection and Complex Cranioplasty. J Surgery. 2015;3(1): 8.

Table 2: The characteristics of all patients included in this series are reported such as (age, gender, size of skull lesions, site, clinical presentation, pathology, management, complications and follow-up).

\begin{tabular}{|c|c|c|c|c|c|c|c|c|}
\hline Age & Gender & $\begin{array}{l}\text { Size } \\
\text { of the } \\
\text { lesion }\end{array}$ & Clinical presentation & $\begin{array}{l}\text { Site of complex } \\
\text { cranioplasty } \\
\text { \&Management } \\
\text { of the skull } \\
\text { lesion }\end{array}$ & Plastic intervention & Pathology & Complications & Fate \& Follow up \\
\hline 54 & $f$ & $6 \times 7 \mathrm{~cm}$ & $\begin{array}{l}\text { aphasia + left } \\
\text { hemiparesis }\end{array}$ & Left parietal & None & $\begin{array}{c}\text { metastatic carcinoma of } \\
\text { the breast }\end{array}$ & $\begin{array}{c}\text { progressive } \\
\text { systemic } \\
\text { disease with } \\
\text { leptomeningeal } \\
\text { spread + incfreq } \\
\text { of seizures } \\
\text { +cellulitis + septic } \\
\text { shock }\end{array}$ & $\begin{array}{l}7 \text { months of } \\
\text { recurrence-free } \\
\text { survival }\end{array}$ \\
\hline 77 & $f$ & $2 \times 5 \mathrm{~cm}$ & $\begin{array}{l}\text { HA, confusion + left } \\
\text { hemiparesis + slurred } \\
\text { speech }\end{array}$ & $\begin{array}{c}\text { Right } \\
\text { frontotemporal }\end{array}$ & None & $\begin{array}{c}\text { metastatic carcinoma of } \\
\text { the breast }\end{array}$ & $\begin{array}{l}\text { Rt MCA infarction } \\
+ \text { massive edema }\end{array}$ & Death in 10 days \\
\hline 58 & $f$ & $\begin{array}{c}4.1 \times 3.4 \\
\mathrm{~cm}\end{array}$ & scalp mass / swelling & $\begin{array}{l}\text { Right } \\
\text { frontotemporal }\end{array}$ & None & $\begin{array}{c}\text { metastatic } \\
\text { adenocarcinoma of the } \\
\text { breast }\end{array}$ & no & $\begin{array}{l}6 \text { months of } \\
\text { recurrence-free } \\
\text { survival }\end{array}$ \\
\hline 58 & $f$ & $\begin{array}{l}4.7 \times 4.1 \\
\times 4.3 \mathrm{~cm}\end{array}$ & $\begin{array}{l}\text { retroauricular bump + } \\
\text { nausea + vomiting }\end{array}$ & $\begin{array}{c}\text { Right posterior } \\
\text { auricular } \\
\text { combined supra } \\
\text { \& infra tentorial + } \\
\text { WBXRT }\end{array}$ & None & $\begin{array}{l}\text { metastatic cancer of } \\
\text { pancreas }\end{array}$ & $\begin{array}{c}\text { CSF leak } 3 \\
\text { months following } \\
\text { surgery }\end{array}$ & $\begin{array}{l}3 \text { months of } \\
\text { recurrence-free } \\
\text { survival before } \\
\text { revision and removal } \\
\text { of the prosthetic plate }\end{array}$ \\
\hline 79 & $f$ & $8 \mathrm{~cm}$ & $\begin{array}{l}\text { scalp defect with } \\
\text { exposed mesh }\end{array}$ & $\begin{array}{c}\text { Right } \\
\text { frontoparietal } \\
\text { Revision of skull } \\
\text { reconstruction } \\
\text { by \{debridement } \\
\text { + removal of } \\
\text { the exposed } \\
\text { titanium mesh, } \\
\text { MM bone cement } \\
\& \text { pre-radiated } \\
\text { skin\} followed } \\
\text { by \{pericranial } \\
\text { allograft for } \\
\text { duraplasty }+2 \text { ry } \\
\text { porex allograft } \\
\text { cranioplasty\} }\end{array}$ & $\begin{array}{l}\text { free latissimus } \\
\text { muscle transfer } \\
\text { with microvascular } \\
\text { anastomosis + redo } \\
\text { of microvascular } \\
\text { anatomosis with } \\
\text { reverse greater } \\
\text { saphenous vein graft } \\
\text { from rt LL+ STSG for } \\
\text { the scalp }\end{array}$ & $\begin{array}{c}\text { PSH of } \\
\text { Hemangiopericytoma } \\
\text { surgically treated } 15 \\
\text { years ago by excision } \\
\text { and skull reconstruction }\end{array}$ & $\begin{array}{c}\text { impending flap } \\
\text { ischemia + Rt } \\
\text { sided scalp \& } \\
\text { neck hematoma } \\
+ \text { focal (partial) } \\
\text { sensory seizures } \\
3 \text { months later }\end{array}$ & $\begin{array}{l}\text { re-exploration of } \\
\text { right latissimus } \\
\text { flap microvascular } \\
\text { anastomosis + } \\
\text { drainage of neck } \\
\text { hematoma+repair of } \\
\text { the bleeding branch } \\
\text { of reverse saphenous } \\
\text { + autologous } \\
\text { muscle graft from } \\
\text { sternocleidomatoid } \\
3 \text { months of } \\
\text { recurrence-free } \\
\text { survival }\end{array}$ \\
\hline 25 & $\mathrm{~m}$ & $\begin{array}{c}4 \times 3.5 \\
\mathrm{~cm}\end{array}$ & scalp mass / swelling & Left frontal & $\begin{array}{l}\text { serratus anterior } \\
\text { myofascial free flap } \\
\text { and a STSG }\end{array}$ & $\begin{array}{l}\text { Dermatofibrosarcomapro- } \\
\text { tuberans }\end{array}$ & no & $\begin{array}{c}5 \text { years of } \\
\text { Recurrence-free } \\
\text { survival }\end{array}$ \\
\hline 74 & $\mathrm{~m}$ & $\begin{array}{c}10 \times 10 \\
\mathrm{~cm}\end{array}$ & $\begin{array}{l}\text { scalp defect with } \\
\text { exposed calvarium }\end{array}$ & $\begin{array}{l}\text { High bilateral } \\
\text { frontoparietal }\end{array}$ & $\begin{array}{l}\text { scalp advancement } \\
\text { flaps and skin graft }\end{array}$ & Low grade sarcoma & no & $\begin{array}{c}6 \text { years of recurrence- } \\
\text { free survival }\end{array}$ \\
\hline 76 & $\mathrm{~m}$ & $\begin{array}{c}1.7 \times 3.5 \\
\mathrm{~cm}\end{array}$ & $\begin{array}{c}\text { Incidental during regular } \\
\text { follow ups }\end{array}$ & $\begin{array}{c}\text { Bilateral } \\
\text { frontoparietal + } \\
\text { SRS }\end{array}$ & $\begin{array}{l}\text { complex skin closure } \\
\text { with subgaleal } \\
\text { release \& rotational } \\
\text { flap }\end{array}$ & $\begin{array}{l}\text { Anaplastic meningioma } \\
\text { (WHO grade } 3 \text { ) }\end{array}$ & $\begin{array}{c}\text { Rt frontal } \\
\text { intraparenchymal } \\
\text { hematoma }+ \\
\text { radiation induced } \\
\text { encephalopathy }\end{array}$ & $\begin{array}{l}14 \text { months of } \\
\text { recurrence-free } \\
\text { survival } \\
\text { KPS }=50\end{array}$ \\
\hline 85 & $f$ & $2 \times 2 \mathrm{~cm}$ & $\begin{array}{c}\text { scalp defect with } \\
\text { exposed calvarium + } \\
\mathrm{HA}+\text { gait disturbance }\end{array}$ & $\begin{array}{c}\text { bifrontal +partial } \\
\text { frontal lobotomy } \\
+ \text { frontal air sinus } \\
\text { exenteration }\end{array}$ & $\begin{array}{l}\text { latissimus dorsi } \\
\text { muscle free flap \& } \\
\text { STSG + revision of } \\
\text { scalp rotational flap }\end{array}$ & $\begin{array}{c}\text { Squamous cell carcinoma } \\
\text { "poorly differentiated }\end{array}$ & $\begin{array}{c}\text { Recurrent left } \\
\text { chronic subdural } \\
\text { hematoma }+ \\
\text { left uncal and } \\
\text { subfalcine brain } \\
\text { herniation }\end{array}$ & $\begin{array}{c}3 \text { weeks of } \\
\text { recurrence-free } \\
\text { survival then she was } \\
\text { elected to Hospice } \\
\text { service }\end{array}$ \\
\hline 59 & $\mathrm{~m}$ & $\begin{array}{c}2.5 \times 2.5 \\
\mathrm{~cm}\end{array}$ & incidental & Left frontal & None & $\begin{array}{c}\text { intraosseous cavernous } \\
\text { hemangioma }\end{array}$ & None & $\begin{array}{c}6 \text { months of } \\
\text { recurrence-free period }\end{array}$ \\
\hline 77 & $f$ & $2 \times 2 \mathrm{~cm}$ & HA, nausea, vomiting & $\begin{array}{l}\text { Left suboccipital } \\
+ \text { SRS to the } \\
\text { resection cavity }\end{array}$ & None & $\begin{array}{l}\text { Metastatic carcinoma } \\
\text { from Lung (NSCLC) } \\
\text { invading bone of P-fossa }\end{array}$ & None & $\begin{array}{l}3 \text { months of } \\
\text { recurrence-free } \\
\text { survival }\end{array}$ \\
\hline 61 & $f$ & $\begin{array}{l}2.5 \times 5.3 \\
\mathrm{~cm}\end{array}$ & scalp mass / swelling & Rt parietal & None & $\begin{array}{c}\text { Metastatic carcinoma of } \\
\text { breast }\end{array}$ & - & - \\
\hline 68 & $f$ & $\begin{array}{c}3.3 \times 2.1 \\
\mathrm{~cm}\end{array}$ & $\begin{array}{l}\text { Scalp swelling - bony } \\
\text { hump }\end{array}$ & $\begin{array}{c}\text { Left } \\
\text { frontotemporal + } \\
\text { local XRT }\end{array}$ & None & $\begin{array}{l}\text { Atypical meningioma } \\
\text { (WHO grade II) }\end{array}$ & None & $\begin{array}{l}5.5 \text { years of } \\
\text { recurrence-free } \\
\text { survival }\end{array}$ \\
\hline
\end{tabular}


Citation: Bayoumi AB, Nigim F, Mahadevan A, Anderson M, Lin SJ, et al. A Case-Series of Solitary Skull Neoplastic Lesions Treated with EnBlock Resection and Complex Cranioplasty. J Surgery. 2015;3(1): 8.

ISSN: 2332-4139

\begin{tabular}{|c|c|c|c|c|c|c|c|c|}
\hline 54 & $\mathrm{~m}$ & $2 \times 1 \mathrm{~cm}$ & $\mathrm{HA}$ & Rt frontal & None & $\begin{array}{c}\text { metastatic carcinoma of } \\
\text { HCC }\end{array}$ & $\begin{array}{l}2 \text { New lesions } \\
\text { (left frontal \&Rt } \\
\text { occipital) treated } \\
\text { by SRS }\end{array}$ & $\begin{array}{l}16 \text { months of } \\
\text { recurrence-free } \\
\text { survival }\end{array}$ \\
\hline 65 & $f$ & $1 \times 3 \mathrm{~cm}$ & scalp mass / swelling & $\begin{array}{l}\text { Left parietal } \\
\text { craniotomy + } \\
\text { WBXRT }\end{array}$ & None & $\begin{array}{c}\text { metastaic carcinoma } \\
\text { of the breast }+ \\
\text { intraoperative evidence of } \\
\text { subarachnoid invasion }\end{array}$ & None & $\begin{array}{l}3 \text { months of } \\
\text { recurrence-free } \\
\text { survival }\end{array}$ \\
\hline 20 & $f$ & $\begin{array}{c}2.5 \times 1.5 \\
\mathrm{~cm}\end{array}$ & $\begin{array}{l}\text { dizziness, nausea, } \\
\text { vomiting }\end{array}$ & $\begin{array}{l}\text { Rt combined } \\
\text { craniectomy } \\
\text { supra } \\
\text { \&infratentorial }\end{array}$ & None & epidermoid cyst & None & $\begin{array}{l}3 \text { months of follow up } \\
\text { with no evidence of } \\
\text { recurrence }\end{array}$ \\
\hline
\end{tabular}

(HA: Headache; m: male; f: female; SRS: Stereotactic Radiosurgery; KPS: Karnofsky Performance Score; MM: Methyl Methacrylate) All patients were followed except for one patient who was referred to another facility closer to his new home address

group of 126 patients with variable indications for cranioplasty (including trauma, stroke and tumors). These authors stated distinct advantages of intraoperatively-fashioned acrylic implants over titanium constructs and pointed out that intraoperative constructs obviate the need of extensive planning [29]. However, this finding did not translate into statistical significance. In our study, we tried to combine both strategies of "complex cranioplasty" by adding a polymethylmethacrylate (PMMA) cement to the scaffolding created by the titanium mesh which admittedly is somewhat more timeconsuming but suitable in the elective setting of skull tumors assessed in this series.

The final decision of offering a complex reconstruction is almost always multifactorial and based on the patient's clinical presentation, type of pathology, anatomical location, extent of lesion, life expectancy and the management plan for the systemic disease. For adequate surgical planning and consensus decisions we offer our patients a specialized multidisciplinary team approach of both neurosurgeons and plastic surgeons. This allows the team to offer a decompression by en-block tumor resection (with microscopic brain dissection if brain invasion is noted) as well as the most suitable soft tissue reconstruction -if needed-using various techniques of flaps and or grafts to achieve adequate closure (see Table 1). Furthermore, an expert senior anesthesiologist should be consulted early on for best surgical planning because of the expected length of such procedures and specific needs for positioning allowing dual access to tissue donor and recipient sites.

The limitations of our report of the series are several folds: This remains a relatively small number of highly selected cases and we did not have a control group treated by any conservative strategy. However, the reported cohort treated this way is larger than previous series and focuses on neoplastic origins of skull defects in all of the 17 cases. The retrospective design of this study limits the ability to control for possible bias in patient selection but our intent was to offer patients who were previously considered not candidates for surgery. That explains the rarity of this scenario as those cases were collected over a 9-year period at our institution.

By showing that multilayer resections and simultaneous reconstructions can be done even for complicated patients, we hope to encourage others to consider this multidisciplinary approach so that a larger number of patients can be added to this series in the future. This may ultimately allow multi-center pooling of data from similar cases and result in the validation of this strategy and the possibility to establish stringent indications which can be considered for selected patients by different teams.

\section{Conclusion}

Single step excisional craniectomy with simultaneous complex cranioplasty can be offered for patients with solitary skull neoplastic lesions with multilayer involvement for lesions of benign, primary malignant or secondary malignant "metastatic origin". Careful patient selection and a multidisciplinary team approach are the key elements in undertaking such complex surgical procedures and help to minimize possible complications.

\section{References}

1. Shaffrey ME, Persing JA, Shaffrey Cl, Delashaw JB, Jane JA (1993) Craniofacial Reconstruction. In: Apuzzo MLJ, editor. Brain Surgery. New York: Churchill-Livingston, p. 1373-1398.

2. Artico M, De Caro GM, Salvati M, Carloia S, Rastelli E, et al. (2000) Solitary metastases to the cranial vault. Report of ten cases. J Neurosurg Sci 44: $33-$ 38.

3. Michael CB, Gokaslan ZL, DeMonte F, McCutcheon IE, Sawaya R, et al. (2001) Surgical resection of calvarial metastases overlying dural sinuses. Neurosurgery 48: 745-754.

4. Weiford EC, Gardner WJ (1949) Tantalum cranioplasty; review of 106 cases in civilian practice. J Neurosurg 6: 13-32.

5. Stula D (1984) Cranioplasty. New York: Sprnger-Veralg.

6. Fodstad H, Love JA, Ekstedt J, Friden H, Liliequist B (1984) Effect of cranioplasty on cerebrospinal fluid hydrodynamics in patients with the syndrome of the trephined. Acta neurochir (Wen) 70: 21-30.

7. Lee JC, Kleiber GM, Pelletier AT, Reid RR, Gottlieb LJ (2013) Autologous immediate cranioplasty with vascularized bone in high-risk composite cranial defects. Plast Reconstr Surg 132: 967-975.

8. Stark AM, Eichmann T, Mehdorn HM (2003) Skull metastases: clinical features, differential diagnosis, and review of the literature. Surg Neurol 60: 219-225.

9. Pikis S, Goldstein J, Spektor S (2014) Potential neurotoxic effects of polymethylmethacrylate during cranioplasty. J Clin Neurosci 22: 139-143.

10. Donaldson AJ, Thomson HE, Harper NJ, Kenny NW (2009) Bone cement implantation syndrome. Br J Anaesth 102: 12-22.

11. Razuin R, Effat O, Shahidan MN, Shama DV, Miswan MF (2013) Bone 
Citation: Bayoumi AB, Nigim F, Mahadevan A, Anderson M, Lin SJ, et al. A Case-Series of Solitary Skull Neoplastic Lesions Treated with EnBlock Resection and Complex Cranioplasty. J Surgery. 2015;3(1): 8.

cement implantation syndrome. Malays J Pathol 35: 87-90.

12. Lee SC, Wu CT, Lee ST, Chen PJ (2009) Cranioplasty using polymethyl methacrylate prostheses. J Clin Neurosci 16: 56-63.

13. Moreira-Gonzalez A, Jackson IT, Miyawaki T, Barakat K, DiNick V (2003) Clinical outcome in cranioplasty: critical review in long-term follow-up. J Craniofac Surg 14: 144-153.

14. Zins JE, Langevin CJ, Nasir S (2010) Controversies in skull reconstruction. J Craniofac Surg 21: 1755-1760.

15. Williams LR, Fan KF, Bentley RP (2014) Custom-made titanium cranioplasty: early and late complications of 151 cranioplasties and review of the literature. Int J Oral Maxillofac Surg [Epub ahead of print].

16. Kshettry VR, Hardy S, Weil RJ, Angelov L, Barnett GH (2012) Immediate titanium cranioplasty after debridement and craniectomy for postcraniotomy surgical site infection. Neurosurgery 70: 8-14.

17. Sahoo N, Roy ID, Desai AP, Gupta V (2010) Comparative evaluation of autogenous calvarial bone graft and alloplastic materials for secondary reconstruction of cranial defects. J Craniofac Surg 21: 79-82.

18. Vahtsevanos K, Triaridis S, Patrikidou A, Uttley D, Moore AJ, et al. (2007) The Atkinson Morley's Hospital joint neurosurgical-maxillofacial procedures: cranioplasty case series 1985-2003. J Craniomaxillofac Surg 35: 336-342.

19. Joffe J, Harris M, Kahugu F, Nicoll S, Linney A, et al. (1999) A prospective study of computer-aided design and manufacture of titanium plate for cranioplasty and its clinical outcome. Br J Neurosurg 13: 576-580.

20. Ducic $Y$ (2002) Titanium mesh and hydroxyapatite cement cranioplasty: a report of 20 cases. J Oral Maxillofac Surg 60: 272-276.
21. Akan M, Karaca M, Eker G, Karanfil H, Akoz T (2011) Is polymethylmethacrylate reliable and practical in full-thickness cranial defect reconstructions? J Craniofac Surg 22: 1236-1239.

22. Blum KS, Schneider SJ, Rosenthal AD (1997) Methyl methacrylate cranioplasty in children: long-term results. Pediatr Neurosurg 26: 33-35.

23. Cheng YK, Weng HH, Yang JT, Lee MH, Wang TC, et al. (2008) Factors affecting graft infection after cranioplasty. J Clin Neurosci 15: 1115-1119.

24. D'Urso PS, Earwaker WJ, Barker TM, Redmond MJ, Thompson RG, et al. (2000) Custom cranioplasty using stereolithography and acrylic. Br J Plast Surg 53: 200-204.

25. Goh RC, Chang CN, Lin CL, Lo LJ (2010) Customised fabricated implants after previous failed cranioplasty. J Plast Reconstr Aesthet Surg 63: 14791484.

26. Marchac D, Greensmith A (2008) Long-term experience with methylmethacrylate cranioplasty in craniofacial surgery. J Plast Reconstr Aesthet Surg 61: 744-752.

27. Kriegel RJ, Schaller C, Clusmann H (2007) Cranioplasty for large skull defects with PMMA (Polymethylmethacrylate) or Tutoplast processed autogenic bone grafts. Zentralbl Neurochir 68: 182-189.

28. Afifi A, Djohan RS, Hammert W, Papay FA, Barnett AE, et al. (2010) Lessons learned reconstructing complex scalp defects using free flaps and a cranioplasty in one stage. J Craniofac Surg 21: 1205-1209.

29. Al-Tamimi YZ, Sinha P, Trivedi M, Robson C, Al-Musawi TA, et al. (2012) Comparison of acrylic and titanium cranioplasty. Br J Neurosurg 26: 510-513. 